Sorption and Precipitation of Plutonium in the Presence of Goethite at Elevated Temperatures

P. Zhao, M. Zavarin, A. B. Kersting, S. A. Carroll

February 2, 2011 
This document was prepared as an account of work sponsored by an agency of the United States government. Neither the United States government nor Lawrence Livermore National Security, LLC, nor any of their employees makes any warranty, expressed or implied, or assumes any legal liability or responsibility for the accuracy, completeness, or usefulness of any information, apparatus, product, or process disclosed, or represents that its use would not infringe privately owned rights. Reference herein to any specific commercial product, process, or service by trade name, trademark, manufacturer, or otherwise does not necessarily constitute or imply its endorsement, recommendation, or favoring by the United States government or Lawrence Livermore National Security, LLC. The views and opinions of authors expressed herein do not necessarily state or reflect those of the United States government or Lawrence Livermore National Security, LLC, and shall not be used for advertising or product endorsement purposes.

This work performed under the auspices of the U.S. Department of Energy by Lawrence Livermore National Laboratory under Contract DE-AC52-07NA27344. 


\section{Sorption and Precipitation of Plutonium in the Presence of Goethite at Elevated Temperatures}

Final Report: Submitted to Natural Systems, Used Fuel Disposition Program

Authors: Mavrik Zavarin, Pihong Zhao, Zurong Dai, Susan A. Carroll and Annie B. Kersting

Glenn T. Seaborg Institute, Physical and Life Sciences Directorate, Lawrence Livermore National Laboratory

\section{INTRODUCTION}

A major challenge in predicting the mobility and transport of actinides in the natural environment is determining the dominant geochemical processes that control their behavior in the subsurface. The reaction chemistry of Pu (i.e., aqueous speciation, solubility, sorptivity, redox chemistry, and affinity for colloidal particles, both abiotic and microbially-mediated) is particularly complicated. Its migration is known to be oxidation-state dependent and facilitated by transport on particulate matter (i.e., colloidal particles). Despite the recognized importance of colloid-facilitated transport, very little is known about the geochemical and biochemical mechanisms controlling Pu-colloid formation and stability. The interest in understanding the behavior of $\mathrm{Pu}$ in the natural environment encompasses both high concentrations expected at the source location and extremely low concentrations encountered at significant distances from the source. Its behavior must be understood over a 10 order of magnitude concentration range, from solubility-controlled ( $>5 \times 10^{-9} \mathrm{M}$, Neck et al. (2007)) near-field concentrations to sorptioncontrolled $\left(10^{-12}-10^{-18} \mathrm{M}\right)$ far field concentrations. The relevant processes that control the behavior of $\mathrm{Pu}$ in the subsurface are not the same across this large range of concentrations and experimental results at high concentrations cannot simply be scaled to low concentrations. For example, at higher concentrations, Pu tends to form intrinsic nano-colloids (Neck et al., 2007); it is not known whether these nano-colloids are produced or are stable at very low (e.g. femtomolar) concentrations. The source locations at future radioactive waste repositories will also likely involve environments at elevated temperatures. The effects of elevated temperature on the behavior of Pu are currently unknown.

Reactive transport models that address geochemical processes occurring at the mineral-water interface are still in their infancy for multi-phase systems (U.S. Department of Energy, 2007). Generally, existing transport models have ignored the coupled factors of redox chemistry and microbial activity and have relied on empirical equilibrium or rate-limited $\mathrm{K}_{\mathrm{d}}$ models to address actinide retardation and colloid-facilitated transport (e.g. (Glynn, 2003; Pickett, 2005; Tien and Jen, 2007)). Recent experimental data from Powell and others (Demirkanli et al., 2008; Kaplan et al., 2004; Kaplan et al., 2006; Powell et al., 2005) suggest that these simplified models cannot adequately predict Pu transport because they do not capture the coupled processes controlling $\mathrm{Pu}$ uptake and release. Significant breakthroughs in our conceptual model of Pu transport will only occur through an improved understanding of the geochemical processes that occur at the mineral-water interface (e.g. sorption, desorption, colloidal formation) at a range of concentrations and relevant environmental conditions. 


\section{OBJECTIVES AND HYPOTHESIS}

Our goal for the FY10 study and the follow-on work in FY11 is to evaluate the sorption behavior of $\mathrm{Pu}$ at elevated temperatures in the presence of relevant minerals and over a range of concentrations that span environmental conditions from the near-field to the far-field. Our effort in FY10 focused on the behavior of two common forms of Pu: aqueous $\mathrm{Pu}(\mathrm{IV})$ and intrinsic $\mathrm{Pu}(\mathrm{IV})$ nano-colloids. We examined to sorption behavior of these two forms of Pu with iron oxide (goethite, $\alpha-\mathrm{FeOOH}$ ) at 25 and $80^{\circ} \mathrm{C}$. In early FY11, we characterized the morphology of $\mathrm{Pu}$ sorbed to goethite using transmission electron microscopy (TEM). A second set of experiments will be initiated in FY11 to investigate the behavior of Pu in the presence of clays and study the stability of sorbed and surface-precipitated Pu phases. The elevated temperature experiments are leveraged by a parallel on-going effort at LLNL to understand the geochemical mechanisms that control Pu transport at ambient temperatures funded by the Office of Science Subsurface Biogeochemical Research (SBR) program in the Office of Biological and Environmental Research (BER).

Our work for the Used Fuel Disposition (UFD) program tests the hypothesis that sorption/desorption behavior of $\mathrm{Pu}$ is controlled by the morphology of $\mathrm{Pu}$ deposited on mineral substrates which, in turn, depends on the conditions under which $\mathrm{Pu}$ was deposited (e.g. $\mathrm{Pu}$ concentration, form, temperature, etc.). We predict that sorption can be categorized as mononuclear adsorption, surface precipitation, or weak electrostatic interaction between intrinsic $\mathrm{Pu}$ nano-colloids or amorphous precipitates and mineral surfaces. The rates of formation and stability of each form will be dependent on solution conditions, substrate characteristics, and temperature. Down-gradient transport of Pu will be determined by its stability as a colloidal form (intrinsic or otherwise). The results of these efforts will provide a clearer understanding of how Pu can migrate over significant temporal and spatial scales (e.g. (Kersting et al., 1999; Novikov et al., 2006; Xu et al., 2006).

\section{EXPERIMENTAL PROCEDURE}

We began testing our hypothesis by examining the behavior of $\mathrm{Pu}$ in the presence of goethite ( $\alpha$ $\mathrm{FeOOH}$ ), an iron oxyhydroxide commonly found in subsurface soils. Two series of batch sorption experiments were conducted. In the first series, aqueous $\mathrm{Pu}(\mathrm{IV})$ was reacted with goethite at 25 and $80^{\circ} \mathrm{C}$. The experiment was intended to test whether the affinity or morphology of sorbed $\mathrm{Pu}$ was temperature dependent. The experiment was performed under identical solution conditions used in an earlier $25^{\circ} \mathrm{C}$ sorption isotherm experiment $(0.1 \mathrm{~g} / \mathrm{L}$ goethite, $\mathrm{pH}$ 8, $5 \mathrm{mM} \mathrm{NaCl} / 0.7 \mathrm{mM} \mathrm{NaHCO}_{3}$ ) (Zhao et al., 2010). However, in the present case, samples were equilibrated for three months rather than two weeks. Comparison of the present data to earlier isotherm data allowed us to evaluate the kinetic aspects of aqueous $\mathrm{Pu}(\mathrm{IV})$ sorption.

In the second set of experiments, intrinsic $\mathrm{Pu}(\mathrm{IV})$ nano-colloids were reacted with goethite at 25 and $80^{\circ} \mathrm{C}$. The $\mathrm{Pu}(\mathrm{IV})$ nano-colloid sorption experiment was intended to test whether the initial form of Pu affects its sorption behavior and evaluate the stability of Pu(IV) nano-colloids as a function of temperature. Our previous experiments have shown that sorption of aqueous $\mathrm{Pu}(\mathrm{IV})$ 
and $\mathrm{Pu}(\mathrm{V})$ to goethite at $25^{\circ} \mathrm{C}$ results in identical sorption affinities and surface products. We extend our examination to the sorption behavior of $\mathrm{Pu}(\mathrm{IV})$ nano-colloids here.

At the end of the three month batch sorption experiments, Pu concentrations in the liquid phase were measured and compared to published amorphous $\mathrm{PuO}_{2}\left(\mathrm{PuO}_{2}(\mathrm{am}\right.$, hyd $\left.)\right)$ solubility measurements (Neck et al., 2007) and sorption affinities (Zhao et al., 2010). In addition, a detailed characterization of the Pu associated with the goethite mineral surface was conducted using TEM. The combination of liquid phase and surface characterization was used to evaluate the effect of temperature and the comparative behavior of aqueous $\mathrm{Pu}(\mathrm{IV})$ versus nano-colloid $\mathrm{Pu}(\mathrm{IV})$ on Pu sorption characteristics.

\section{Pu stock solution}

Alpha-emitting ${ }^{242} \mathrm{Pu}$ (> 99.8\% by mass) was used in the experiments. The major isotopes contributing to alpha activities are ${ }^{238} \mathrm{Pu},{ }^{239,240} \mathrm{Pu}$ and ${ }^{242} \mathrm{Pu}$ with activity percentages of $15.9 \%$, $5.2 \%$ and $78.9 \%$, respectively. The Pu stock solution $\left(7.6 \times 10^{-4} \mathrm{M} \mathrm{Pu}(\mathrm{IV})\right.$ in $\left.2.06 \mathrm{M} \mathrm{HCl}\right)$ was purified using AG1x8 100-200 mesh anion exchange resin and filtered through a 3kD molecular weight cut-off (MWCO) filter. The oxidation state of Pu was confirmed using both UV/VIS and solvent extraction. The aqueous $\mathrm{Pu}(\mathrm{IV})$ working solution was prepared by diluting the stock solution to $1.9 \times 10^{-4} \mathrm{M} \mathrm{Pu}(\mathrm{IV})$ in $1 \mathrm{~N} \mathrm{HCl}$. The intrinsic Pu(IV) nano-colloid working solutions was prepared by adding $1 \mathrm{~mL} 1 \mathrm{~N} \mathrm{NaOH}$ and $0.39 \mathrm{~mL} \mathrm{pH} 8$ buffer $(5 \mathrm{mM} \mathrm{NaCl} / 0.7 \mathrm{mM}$ $\mathrm{NaHCO}_{3}$ ) to $0.53 \mathrm{~mL}$ of the $\mathrm{Pu}(\mathrm{IV})$ stock. Another $0.06 \mathrm{~mL}$ of $1 \mathrm{~N} \mathrm{NaOH}$ was added gradually to adjust the $\mathrm{pH}$ to $\sim 8.5$. The final $\mathrm{Pu}(\mathrm{IV})$ nano-colloid concentration was $1.5 \times 10^{-4}$. The $\mathrm{Pu}(\mathrm{IV})$ nano-colloids were retained by $3 \mathrm{kD}$ MWCO filter. Thus, we estimate that the nano-colloid size was generally $>1 \mathrm{~nm}$. The fundamental particle size of intrinsic Pu nano-colloids prepared in this manner is 2-5 nm (Figure 1). However, aggregation of these nano-colloids is commonly observed such that the aggregate size is larger (Powell et al., in press).

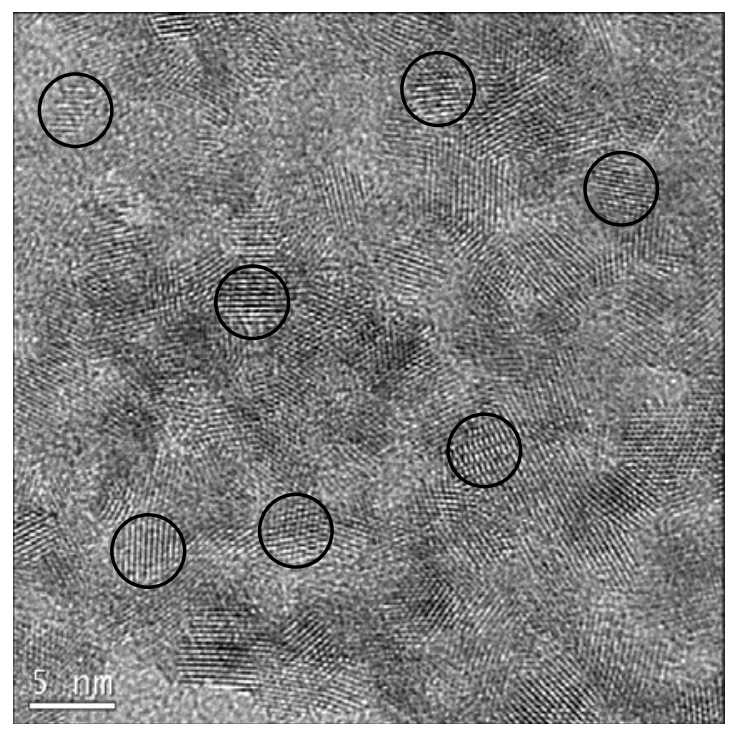

Figure 1. HRTEM of aggregated intrinsic Pu(IV) nano-colloids. Circles identify Pu(IV) nano-colloid locations. 


\section{Goethite preparation}

Goethite was synthesized from $\mathrm{Fe}\left(\mathrm{NO}_{3}\right)_{3} \bullet 9 \mathrm{H}_{2} \mathrm{O}$ as described by Schwertmann and Cornell (1991). Goethite was washed with a $5 \mathrm{mM} \mathrm{NaCl} / 0.7 \mathrm{mM} \mathrm{NaHCO}_{3}$ buffer solution, sonicated for 5 minutes, and centrifuged for 60 minutes at $3500 \mathrm{rpm}$ three times until constant $\mathrm{pH}$ was reached. Based on a spherical particle sedimentation estimate (Gee and Bauder, 1986), the goethite particle size retained was $>100 \mathrm{~nm}$. X-ray diffraction confirmed goethite as the major phase, the point of zero salt effect was $8.5 \pm 0.1$ and the BET surface area was $16 \mathrm{~m}^{2} / \mathrm{g}$. Additional characterization details can be found in Powell et al. (2008a).

\section{Batch experiments}

All batch experiments were conducted in $10 \mathrm{~mL}$ Nalgene* Oak Ridge polycarbonate centrifuge tubes with sealing caps. Either aqueous $\mathrm{Pu}(\mathrm{IV})$ or intrinsic $\mathrm{Pu}(\mathrm{IV})$ nano-colloids were spiked into $9 \mathrm{~mL}$ of $5 \mathrm{mM} \mathrm{NaCl} / 0.7 \mathrm{mM} \mathrm{NaHCO}_{3}$ in which goethite (solid to liquid ratio of $0.1 \mathrm{~g} / \mathrm{L}$ ) had previously been added. Goethite-free Pu solutions were prepared in parallel. For the aqueous $\mathrm{Pu}(\mathrm{IV})$ experiments, an equivalent amount of $\mathrm{NaOH}$ was added before adding the Pu spike to ensure a final solution $\mathrm{pH}$ of 8 . The $10 \mathrm{~mL}$ tubes were submerged in $50 \mathrm{~mL}$ polypropylene conical centrifuge tubes filled with MQ water to minimize evaporative losses and provide secondary containment to the radioactive samples. Over the course of the experiment, the $25^{\circ} \mathrm{C}$ sample tubes were stored vertically in a hood. The $80^{\circ} \mathrm{C}$ sample tubes were submerged in a heated water bath. Samples were periodically shaken and weighed to check for fluid evaporative losses; no significant loss of fluid was observed over the course of the experiment.

Three initial Pu concentrations were used in each of the two sorption experiment series (Table 1) such that the resulting equilibrium Pu concentration would be below, above, and near the $\mathrm{PuO}_{2}$ (am, hyd) solubility ( $\sim \times 10^{-9} \mathrm{M}$ ) (Neck et al., 2007). Two goethite-free solutions (spiked blanks) with initial $\mathrm{Pu}$ concentrations below and above $\mathrm{PuO}_{2}(\mathrm{am}$, hyd) solubility were used for comparison with sorption experiments. All solutions were allowed to react for 103 days.

At the conclusion of each experiment, two samples were taken from each tube. The first supernatant sample was taken after the goethite was allowed to settle out for 60 hrs. Based on sedimentation rates, we estimate that the supernatant included particles $<\sim 250 \mathrm{~nm}$ on average (Table 2). The second supernatant sample was collected after centrifugation at $5000 \mathrm{rpm}$ for 90 minutes at room temperature. In this case, the supernatant included particles $<\sim 25 \mathrm{~nm}$ on average. Because the $80^{\circ} \mathrm{C}$ sample centrifugation occurred at $25^{\circ} \mathrm{C}$, there is a possibility that this experimental artifact could affect the results. The specific particle size cut off for samples is listed in Table 2. Centrifugation was expected to effectively remove goethite (>100 nm) particles. Sedimentation was expected to remove the majority of goethite from solution. Nevertheless, Fe in solution was monitored by ICP-MS. In all cases, Fe concentrations were low enough such that the contribution of goethite to the measured Pu solution concentration was predicted to be negligible $(<0.2 \%$ of $\mathrm{Pu}$ in solution). Neither sedimentation nor centrifugation was expected to quantitatively remove dispersed $\mathrm{Pu}(\mathrm{IV})$ nano-colloids from solution. However, centrifugation would likely remove most aggregated nano-colloids. A comparison of the sedimentation and centrifugation supernatants provides information on the presence of intermediate-sized colloid particles in solution (25-250 nm). These may be small goethite particles with sorbed Pu but are 
more likely large aggregated intrinsic Pu nano-colloids.

Table 1. Experimental conditions for Pu(IV) samples at 25 and $80^{\circ} \mathrm{C}$

\begin{tabular}{|c|c|c|c|c|c|}
\hline $\begin{array}{l}\text { Sample } \\
\text { Number }\end{array}$ & Pu form & Initial Pu & $\begin{array}{c}\text { Goethite } \\
\text { concentration }\end{array}$ & $\begin{array}{c}\text { Predicted } \\
\text { equilibrium } \\
\text { aqueous } \mathrm{Pu}^{\mathrm{a}}\end{array}$ & $\begin{array}{c}\text { Predicted } \\
\text { surface load } \\
\text { on goethite }^{b}\end{array}$ \\
\hline
\end{tabular}

\begin{tabular}{lccccc}
\hline & & $\mathrm{mol} / \mathrm{L}$ & $\mathrm{g} / \mathrm{L}$ & $\mathrm{mol} / \mathrm{L}$ & fraction \\
\hline 1 & Aqueous & $7.3 \times 10^{-11}$ & 0 & - & - \\
2 & Aqueous & $8.0 \times 10^{-7}$ & 0 & - & - \\
3 & Colloidal & $9.6 \times 10^{-11}$ & 0 & - & - \\
4 & Colloidal & $7.3 \times 10^{-7}$ & 0 & - & - \\
\hline 5 & Aqueous & $3.8 \times 10^{-9}$ & 0.1 & $3.8 \times 10^{-12}$ & 0.0005 \\
6 & Aqueous & $7.8 \times 10^{-7}$ & 0.1 & $7.8 \times 10^{-10}$ & 0.1 \\
7 & Aqueous & $3.8 \times 10^{-6}$ & 0.1 & $3.8 \times 10^{-9}$ & 0.5 \\
8 & Colloidal & $3.1 \times 10^{-8}$ & 0.1 & $3.1 \times 10^{-11}$ & 0.005 \\
9 & Colloidal & $7.3 \times 10^{-7}$ & 0.1 & $7.3 \times 10^{-10}$ & 0.1 \\
10 & Colloidal & $3.7 \times 10^{-6}$ & 0.1 & $3.7 \times 10^{-9}$ & 0.5 \\
\hline
\end{tabular}

${ }^{a}$ Based on a Pu $\mathrm{K}_{\mathrm{d}}$ of $3 \times 10^{6} \mathrm{~mL} / \mathrm{g}$ from Powell et al. (2008b).

b Surface loading estimated using $0.1 \mathrm{~g} / \mathrm{L}$ goethite, $16 \mathrm{~m} / \mathrm{g}$, and a site density of 2.31 sites $/ \mathrm{nm}^{2}$ (Dzombak and Morel, 1990).

Table 2. Particle segregation methods and associated particle size cut-offs

\begin{tabular}{lccc}
\hline $\begin{array}{l}\text { Particle segregation } \\
\text { method }\end{array}$ & Particle & Temperature & $\begin{array}{c}\text { Particle size } \\
\text { cut-off }\end{array}$ \\
\hline Sedimentation & Goethite & 25 & $\mathrm{~nm}$ \\
Sedimentation & $\mathrm{PuO}_{2}$ (am, hyd) & 25 & 375 \\
Sedimentation & $\mathrm{Goethite}^{\mathrm{C}}$ & 80 & 225 \\
Sedimentation & $\mathrm{PuO}_{2}$ (am, hyd) & 80 & 125 \\
\hline Centrifugation & $\mathrm{Goethite}$ & 25 & 35 \\
Centrifugation & $\mathrm{PuO}_{2}$ (am, hyd) & 25 & 19 \\
\hline a Sedimentation rates were calculated using goethite and $\mathrm{PuO}_{2}$ \\
densities of 4.27 and $11.5 \mathrm{~g} / \mathrm{cm}^{3}$. Fluid viscosity used at 25 \\
and $80^{\circ} \mathrm{C}$ were $8.90 \times 10^{-4}$ and $3.55 \times 10^{-4}$, respectively. The \\
fluid density used at 25 and $80^{\circ} \mathrm{C}$ was 0.997 and $0.972 \mathrm{~g} / \mathrm{cm}^{3}$, \\
respectively. Sedimentation was rounded to the nearest $25 \mathrm{~nm}$.
\end{tabular}

\section{$\mathrm{Pu}$ analysis}

Both liquid scintillation counting (LSC) and ICP-MS measurements were used to determine $\mathrm{Pu}$ concentration. The LSC was used for samples with high Pu and ICP-MS used for samples in which Pu concentrations were below LSC method detection limit $\left(\sim 3 \times 10^{-10} \mathrm{M}\right)$. It is important to consider the fact that sedimentation and centrifugation only segregate particles greater than the associated particle size cut off. Thus, the measured Pu concentration in solution represents both 
aqueous $\mathrm{Pu}$ and $\mathrm{Pu}$ nano-colloids (or aggregates) smaller than the cutoff size for sedimentation or centrifugation (Table 2).

\section{TEM sample preparation and analysis}

At the conclusion of each experiment, the solid phases were washed in MQ (>18 M $\Omega$ ) water three times by sequentially centrifuging at $5000 \mathrm{rpm}$ for 90 minutes, decanting the supernatant, and replacing it with fresh MQ water. The washing was performed to remove salts from solution. The solids were re-suspended in MQ water by sonicating for 5 minutes and diluting $10 \times$ to produce a $0.01 \mathrm{~g} / \mathrm{L}$ suspension. A volume of 2 to $5 \mathrm{uL}$ of each suspension was deposited on TEM carbon-coated copper grids and dried in a glass desiccator. All analyses were performed on a Philips CM 300 FEG TEM operating at 300kV and equipped with a Gatan Imaging Filter (GIF) with a $2 \mathrm{k} \times 2 \mathrm{k}$ CCD camera and an EDX detector.

\section{RESULTS}

\section{Pu behavior in the absence of goethite}

Spiked-blanks (i.e. goethite-free solutions) were run in parallel with sorption experiments to evaluate loss of $\mathrm{Pu}$ to container walls and homogeneous nucleation of $\mathrm{PuO}_{2}$ (am, hyd) precipitates. Both aqueous $\mathrm{Pu}(\mathrm{IV})$ and intrinsic $\mathrm{Pu}(\mathrm{IV})$ nano-colloid solutions were equilibrated for 103 days at 25 and $80^{\circ} \mathrm{C}$. Initial Pu concentrations were either oversaturated $\left(\sim 10^{-6} \mathrm{M}\right)$ or undersaturated $\left(\sim 10^{-10} \mathrm{M}\right)$ with respect to $\mathrm{PuO}_{2}$ (am, hyd). The solution concentration data are presented in Figure 2. To readily compare these solution concentrations to the solubility of $\mathrm{PuO}_{2}$ (am, hyd), we superimposed our data on the $\mathrm{PuO}_{2}$ (am, hyd) solubility data presented in Figure 5 of Neck et al. (2007). In all undersaturated samples, significant losses of Pu from solution occurred (7090\%) over 103 days. However, we presume that the losses were dominated by sorption to container walls; precipitation of $\mathrm{PuO}_{2}$ (am, hyd) was not anticipated. Formation of Pu nanocolloids from aqueous $\mathrm{Pu}(\mathrm{IV})$, dissolution of $\mathrm{Pu}(\mathrm{IV})$ nano-colloids, or oxidation of $\mathrm{Pu}(\mathrm{IV})$ may have occurred in these samples but we did not attempt to characterize those processes.

In the high concentration $\left(\sim 10^{-6} \mathrm{M}\right)$ samples, the behavior of intrinsic $\mathrm{Pu}(\mathrm{IV})$ nano-colloids and aqueous $\mathrm{Pu}(\mathrm{IV})$ was distinct. Intrinsic $\mathrm{Pu}(\mathrm{IV})$ nano-colloids "precipitated” from solution ( 99.7\%) in equal amounts at both temperatures. The Pu concentration remaining in solution was consistent with the solubility of $\mathrm{PuO}_{2}$ (am, hyd) at $25^{\circ} \mathrm{C}$ as reported in Neck et al. (2007). The loss of $\mathrm{Pu}(\mathrm{IV})$ nano-colloids from solution appears to be driven by the aggregation of $\mathrm{Pu}(\mathrm{IV})$ nano-colloids and not the formation of large ordered precipitates (e.g. Figure 1). The behavior of aqueous $\mathrm{Pu}(\mathrm{IV})$ appeared to be temperature-dependent. At 103 days, the Pu concentration at $80^{\circ} \mathrm{C}$ was two orders of magnitude lower than at $25^{\circ} \mathrm{C}$ (Figure 2). The underlying reason for this is not known. Temperature may affect nano-colloid precipitation rates. However, Neck et al. (2007) results indicate that 100 days is sufficient to expect equilibrium. The aggregation behavior of nano-colloids can also be affected by temperature and solution conditions (e.g. pH, ionic strength) (Garcia-Garcia et al. (2009)). Regardless of temperature, it is clear that homogeneous nucleation and precipitation of $\mathrm{PuO}_{2}$ (am, hyd) will occur under these oversaturated solution conditions and at both temperatures. 


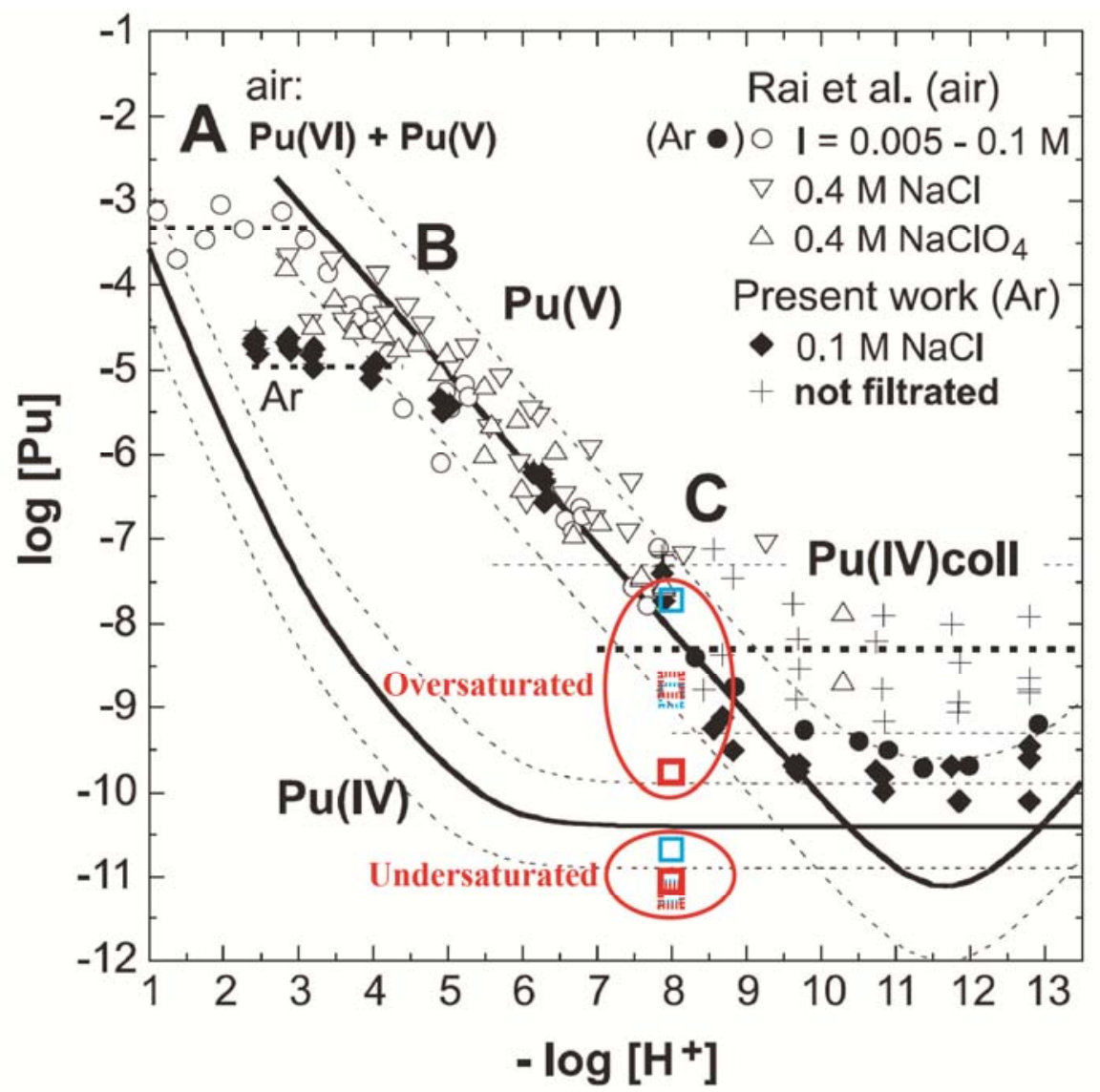

Sample initially spiked with $\mathrm{Pu}(\mathrm{IV}), 25^{\circ} \mathrm{C}$

Sample initially spiked with intrinsic $\mathrm{Pu}(\mathrm{IV})$ nano-colloids, $25^{\circ} \mathrm{C}$

Sample initially spiked with $\mathrm{Pu}(\mathrm{IV}), 80^{\circ} \mathrm{C}$

Sample initially spiked with intrinsic $\mathrm{Pu}(\mathrm{IV})$ nano-colloids, $80^{\circ} \mathrm{C}$

Figure 2. Pu concentrations in eight goethite-free spiked blanks oversaturated (initially $\sim 10^{-6} \mathrm{M}$ ) and undersaturated (initially $10^{-10} \mathrm{M}$ ) with respect to $\mathrm{PuO}_{2}\left(\mathrm{am}\right.$, hyd). Data are superimposed over $\mathrm{PuO}_{2}$ (am, hyd) solubility data reported in Figure 5 from Neck et al. (2007). Homogeneous nucleation and precipitation of aqueous Pu(IV) and intrinsic $\mathrm{Pu}(\mathrm{IV})$ nano-colloids is evident. Pu concentrations in supernatants from sedimentation and centrifugation samples yielded similar results. 
Figure 3 presents the $25^{\circ} \mathrm{C}$ data for the sorption of aqueous $\mathrm{Pu}(\mathrm{IV})$ and intrinsic $\mathrm{Pu}(\mathrm{IV})$ nanocolloid to goethite. For each form of $\mathrm{Pu}$, data at three concentrations are presented. For simplicity, we designate these as low, intermediate, and high concentration samples. For comparison, Figure 3 also includes earlier aqueous $\mathrm{Pu}(\mathrm{IV})$ isotherm data at 7 and 14 days from an experiment performed over a much wider $\mathrm{Pu}(\mathrm{IV})$ concentration range while using the identical mineral and solution conditions (Zhao et al., 2010). Solution concentration data (and associated solid concentrations) are presented based on measured Pu supernatant concentrations after sedimentation (approximately $<250 \mathrm{~nm}$ ) and centrifugation (approximately $<25 \mathrm{~nm}$ ) procedures (Table 2). Differences between measured Pu supernatant concentrations from these two procedures are an indication that $\mathrm{Pu}$ is present in substantial quantities associated with particles in the 25-250 nm range. This may be a combination of Pu sorbed to goethite nanoparticles and aggregated intrinsic Pu(IV) nano-colloids. However, based on ICP-MS measurements of Fe in solution, we believe that the goethite was effectively removed and the majority of those particles are aggregated intrinsic $\mathrm{Pu}(\mathrm{IV})$ nano-colloids.

The present aqueous $\mathrm{Pu}(\mathrm{IV})$ sorption data are in excellent agreement with the earlier isotherm data. First, the low concentration aqueous $\mathrm{Pu}(\mathrm{IV})$ sample matches previous isotherm data (small black symbols), indicating that equilibrium sorption was reached within 7 days. Second, the intermediate concentration aqueous $\mathrm{Pu}(\mathrm{IV})$ sample matches the previous data at 14 days, indicating that sorption/surface precipitation reached equilibrium within 14 days. Third, the highest concentration aqueous $\mathrm{Pu}(\mathrm{IV})$ sample $\left(1.1 \mathrm{x} \mathrm{E}^{-9} \mathrm{M}\right)$ resulted in a solution concentration lower than the earlier 14 day sample, $\left(3.8 \times 10^{-9} \mathrm{M}\right)$ indicating that equilibrium had not been reached within 14 days. For the intermediate and high aqueous $\mathrm{Pu}(\mathrm{IV})$ concentration samples, solubility considerations suggest that precipitation of $\mathrm{PuO}_{2}$ (am, hyd) may occur (initial $\mathrm{Pu}$ concentrations were $8 \times 10^{-7}$ and $4 \times 10^{-6} \mathrm{M}$, respectively, Table 1 ). However, equilibrium solution concentrations are slightly lower than expected based on thermodynamic estimates alone (range of $\mathrm{PuO}_{2}(\mathrm{am}$, hyd) solubility predicted by thermodynamic constants and associated uncertainties from Neck et al. (2007) identified in Figure 2 by grey zone). Neck et al. (2007) suggest that a mixture of colloidal $\mathrm{PuO}_{2}$ and aqueous $\mathrm{Pu}(\mathrm{V})$ will be the predominant forms of $\mathrm{Pu}$ in solution. However, the concentration of colloidal $\mathrm{PuO}_{2}$ is conditional, depending on the choice of particle size range that is considered "colloidal". In the case of Neck et al. (2007), the colloidal fraction was defined as the fraction collected by a $10 \mathrm{kD}(\sim 1.5 \mathrm{~nm}$ pore size) filter from a "clear supernatant". The upper limit of the particle size considered "colloidal” is not strictly defined. In our case, the sedimentation data produces a particle size upper limit of $\sim 250 \mathrm{~nm}$. A higher upper limit used in our case might increase the apparent Pu concentration in solution.

The behavior of intrinsic Pu(IV) nano-colloids differs significantly from that of aqueous $\mathrm{Pu}(\mathrm{IV})$ only in the low concentration sample. A substantial difference between Pu concentration in solution after sedimentation $\left(2.4 \times 10^{-10} \mathrm{M}\right)$ versus centrifugation $\left(9.8 \times 10^{-12} \mathrm{M}\right)$ indicates that large (25-250 nm) aggregated intrinsic $\mathrm{Pu}(\mathrm{IV})$ nano-colloids are present and do not have a strong affinity for the goethite surface (Figure 3). It suggests that intrinsic $\mathrm{Pu}(\mathrm{IV}$ ) nano-colloids at low concentrations may not be subject to sorption processes to goethite that would retard their migration if part of the host rock. However, the intermediate and high concentration samples do 
not exhibit this same behavior. The intermediate and high concentration intrinsic Pu(IV) nanocolloid sorption samples result in solution concentrations similar to aqueous $\mathrm{Pu}(\mathrm{IV})$ sorption samples.

Figure 4 presents the $80^{\circ} \mathrm{C}$ sorption data for aqueous $\mathrm{Pu}(\mathrm{IV})$ and intrinsic $\mathrm{Pu}(\mathrm{IV})$ nano-colloids. The $80^{\circ} \mathrm{C}$ aqueous $\mathrm{Pu}(\mathrm{IV})$ sorption data are similar to the $25^{\circ} \mathrm{C}$ data. However, larger differences in solution Pu concentrations between sedimentation and centrifugation suggest that large 25-250 $\mathrm{nm}$ aggregated intrinsic $\mathrm{Pu}(\mathrm{IV})$ nano-colloids may be more stable at higher temperatures.

Evaluating the desorption and stability characteristics of adsorbed and surface precipitated $\mathrm{Pu}(\mathrm{IV})$ will be the focus for FY12 studies. Morphological and crystallographic characteristics of Pu(IV) sorbed to goethite are discussed in the following section.

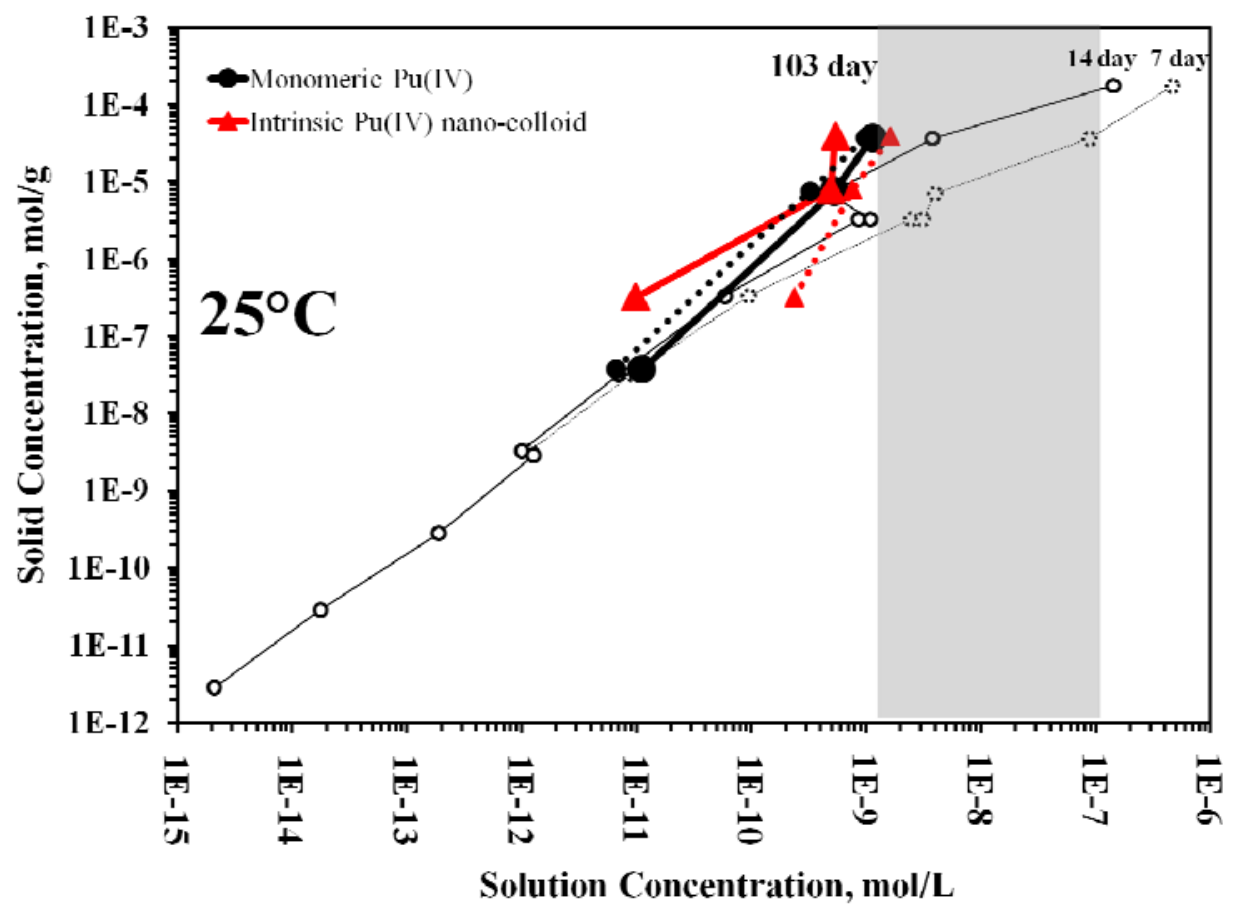

Figure 3. Sorption of aqueous $\mathrm{Pu}(\mathrm{IV})$ (black) and intrinsic $\mathrm{Pu}(\mathrm{IV})$ nano-colloids (red) to goethite at $25^{\circ} \mathrm{C}$. Aqueous concentration based on sedimentation ( $<250 \mathrm{~nm}$, dashed line) and centrifugation ( $<25 \mathrm{~nm}$, solid line). The 7 day and 14 day aqueous $\mathrm{Pu}(\mathrm{IV})$ sorption experiments (small black circles) were performed earlier under identical solution conditions. Gray zone is estimated total Pu concentration in equilibrium with $\mathrm{PuO}_{2}$ (am, hyd) reported in (Neck et al., 2007) for $\mathrm{pH} 8$ solution (dominated by aqueous $\mathrm{Pu}(\mathrm{V})$ and $>1.5 \mathrm{~nm} \mathrm{PuO}_{2}$ colloids). 


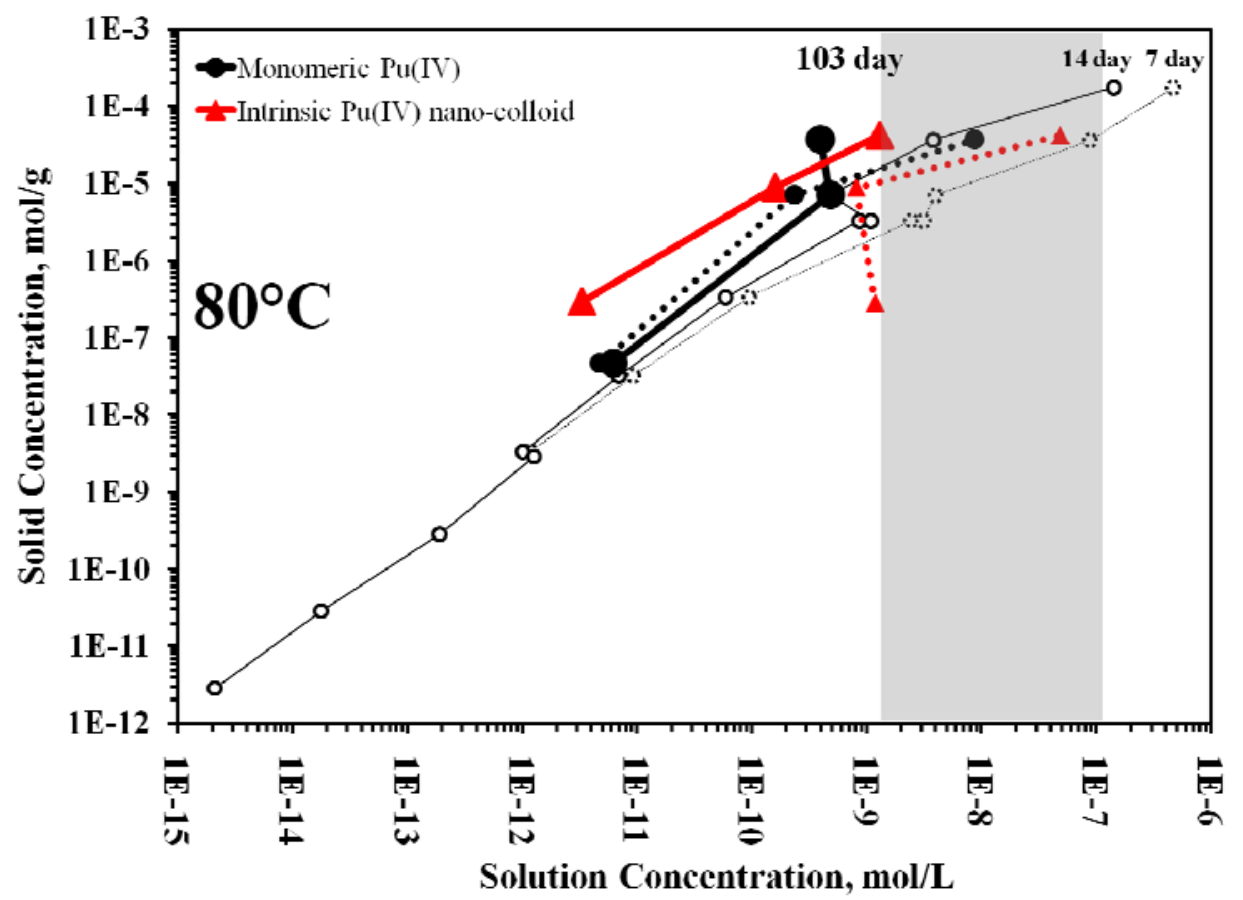

Figure 4. Sorption of aqueous $\mathrm{Pu}(\mathrm{IV})$ (black) and intrinsic $\mathrm{Pu}(\mathrm{IV})$ nano-colloids (red) to goethite at $80^{\circ} \mathrm{C}$. Aqueous concentration based on sedimentation ( $<250 \mathrm{~nm}$, dashed line) and centrifugation ( $<25 \mathrm{~nm}$, solid line). The 7 day and 14 day aqueous $\mathrm{Pu}(\mathrm{IV})$ sorption experiments (small circles) were performed earlier under identical solution conditions. Gray zone is estimated total Pu concentration in equilibrium with $\mathrm{PuO}_{2}(\mathrm{am}$, hyd) reported in (Neck et al., 2007) for $\mathrm{pH} 8$ solution (dominated by aqueous $\mathrm{Pu}(\mathrm{V})$ and $>1.5 \mathrm{~nm} \mathrm{PuO}_{2}$ colloids)

\section{TEM observations of Pu morphology}

\section{$\underline{25^{\circ} \mathrm{C} \text { aqueous } \mathrm{Pu}}$}

In the presence of goethite and at $25^{\circ} \mathrm{C}$, aqueous $\mathrm{Pu}(\mathrm{IV})$ has been shown to grow epitaxially, forming bcc $\mathrm{Pu}_{4} \mathrm{O}_{7}$ nano-colloids in the 2-5 nm particle size range (Powell et al., in press). While previous observations were made on samples reacted for short durations, the $\mathrm{Pu}_{4} \mathrm{O}_{7}$ nanocolloids appear to be stable over the longer experiment timeframe examined here (103 days). In the intermediate concentration sample, $\mathrm{Pu}_{4} \mathrm{O}_{7}$ nano-colloids are widely distributed over the goethite surface and dominated by isolated (dispersed) $2-5 \mathrm{~nm}$ nano-colloids (Figure 5). In the high concentration sample, both dispersed $\mathrm{Pu}_{4} \mathrm{O}_{7}$ nano-colloids and aggregated fcc $\mathrm{PuO}_{2}$ nanocolloids exist (Figure 6). Importantly, the fundamental crystalline size remains in the 2-5 nm size range for both forms of Pu nano-colloid and in all samples. In the high concentration sample, nano-colloid aggregation is more pronounced. It cannot be ascertained whether this aggregation is purely a physical/electrostatic interaction or a chemical one. However, that difference may have a pronounced effect on the transport behavior of intrinsic Pu nano-colloids as well as the transport behavior facilitated by iron oxide colloids. Importantly, aggregated nano-colloids appear to be dominated by $\mathrm{PuO}_{2}$ nano-colloids precipitated directly from solution and weakly associated with the goethite surface. From a bulk solution chemistry standpoint, this would be characterized as precipitation of $\mathrm{PuO}_{2}$ (am, hyd). At the nanoscale, it is characterized as aggregation of $\mathrm{PuO}_{2}$ nano-colloids. 


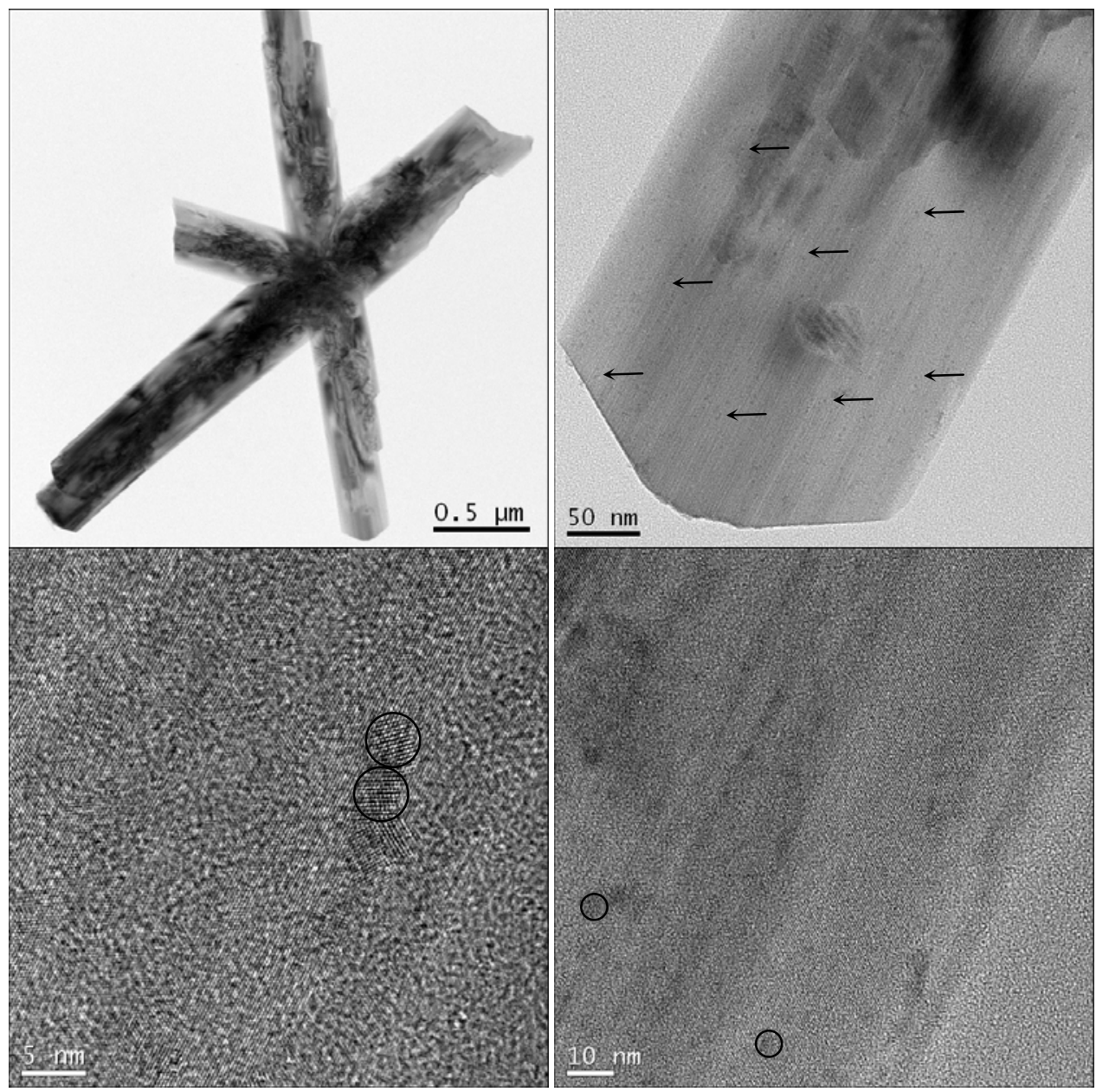

Figure 5. TEM/HRTEM of aqueous Pu(IV) sorbed to goethite at $25^{\circ} \mathrm{C}$ for 103 days at the intermediate concentration. The 1,800 ppm Pu on goethite represents $\sim 10 \%$ surface load. Arrows and circles identify locations where dispersed $\mathrm{Pu}_{4} \mathrm{O}_{7}$ nano-colloids are present. 

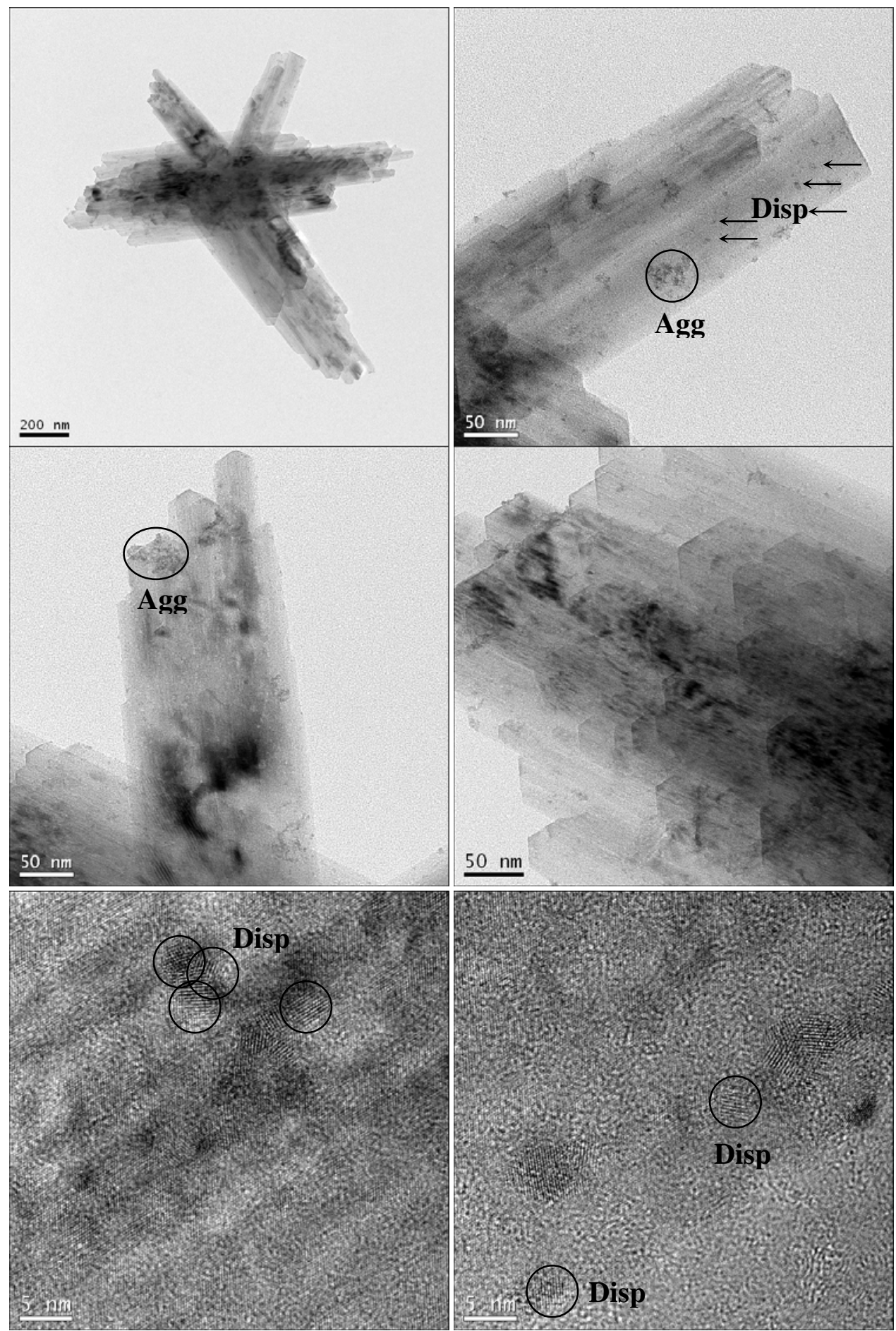

Figure 6. TEM/HRTEM of aqueous Pu(IV) sorbed to goethite at $25^{\circ} \mathrm{C}$ for 103 days, of the high concentration samples. The 8,900 ppm Pu on goethite represents $~ 50 \%$ surface load. Arrows and circles identify locations where aggregated (Agg) $\mathrm{PuO}_{2}$ and dispersed (Disp) $\mathrm{Pu}_{4} \mathrm{O}_{7}$ nano-colloids are present. 


\section{$25^{\circ} \mathrm{C}$ intrinsic Pu nano-colloids}

Unlike aqueous $\mathrm{Pu}(\mathrm{IV})$ sorption, intrinsic $\mathrm{Pu}(\mathrm{IV})$ nano-colloids sorption to goethite is dominated by aggregated mats of $\mathrm{PuO}_{2}$ nano-colloids (Figure 7). These mats were observed in both the intermediate and high concentration samples. The $\mathrm{Pu}_{4} \mathrm{O}_{7}, 2-5 \mathrm{~nm}$, colloids growing on the goethite surface (Figure $5 \& 6$ ) that were observed in the aqueous Pu-experiments were not observed in any of the intrinsic Pu experiments. Only $\mathrm{PuO}_{2}$ nano-colloids were observed. The bulk solution chemistry data (Figure 2) suggest that the same behavior would be observed at the low Pu concentration as well. However, TEM characterization at low surface loading is exceedingly difficult; it was not attempted for the low concentration sample.

Because these mats are located both on and off goethite (Figures 8 and 9), it is clear that the interaction between intrinsic $\mathrm{PuO}_{2}$ nano-colloids and the goethite surface is much weaker than in the case of aqueous $\mathrm{Pu}(\mathrm{IV})$ sorption. The state of the weak interaction between intrinsic $\mathrm{PuO}_{2}$ nano-colloids and the goethite surface (electrostatic or otherwise) cannot be ascertained at this time.

It appears that intrinsic $\mathrm{PuO}_{2}$ nano-colloids, once formed, will not alter to the epitaxial $\mathrm{Pu}_{4} \mathrm{O}_{7}$ on goethite under these conditions. From the bulk solution chemistry data alone, the complex and diverse interaction of aqueous $\mathrm{Pu}(\mathrm{IV})$ and intrinsic $\mathrm{Pu}(\mathrm{IV})$ nano-colloids with goethite could not be discerned. Only through careful TEM analysis can we begin to understand the aqueous vs. intrinsic nature of $\mathrm{Pu}$. The aggregation of intrinsic $\mathrm{PuO}_{2}$ nano-colloids appears, from bulk solution chemistry data, to represent precipitation of $\mathrm{PuO}_{2}$ (am, hyd). However, the ordered $\mathrm{PuO}_{2}$ does not appear to grow beyond its initial 2-5 nm crystalline size. TEM has been use successfully in understanding the behavior of Pu, particularly under conditions where there is a propensity to form nano-colloid and/or amorphous phases. 


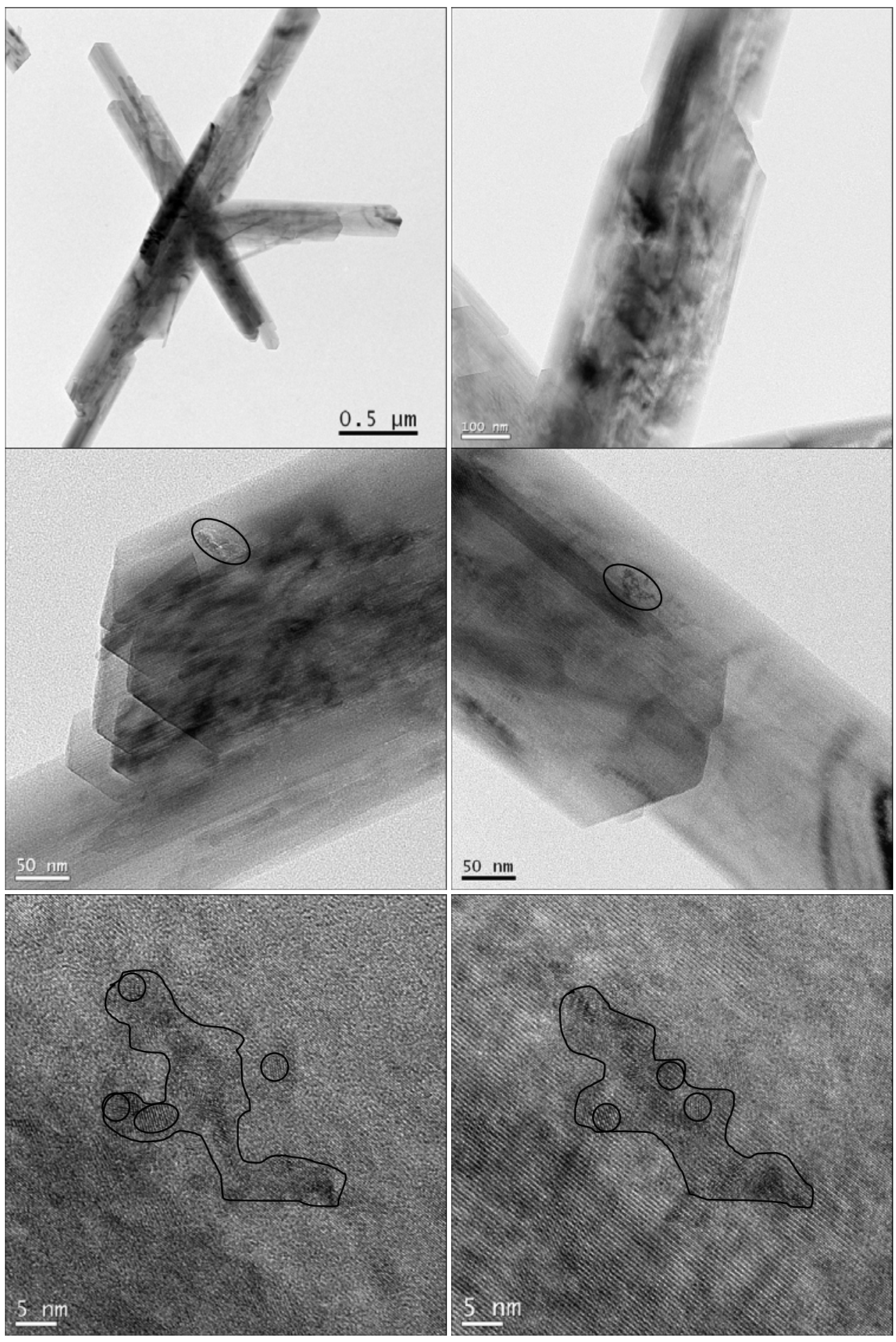

Figure 7. TEM/HRTEM of intrinsic Pu(IV) nano-colloids sorbed to goethite at $25^{\circ} \mathrm{C}$ for 103 days at the intermediate concentration. The $1,900 \mathrm{ppm}$ Pu on goethite represents $\sim 10 \%$ surface load. Circles identify locations where aggregated (Agg) $\mathrm{PuO}_{2}$ nano-colloids are present. 


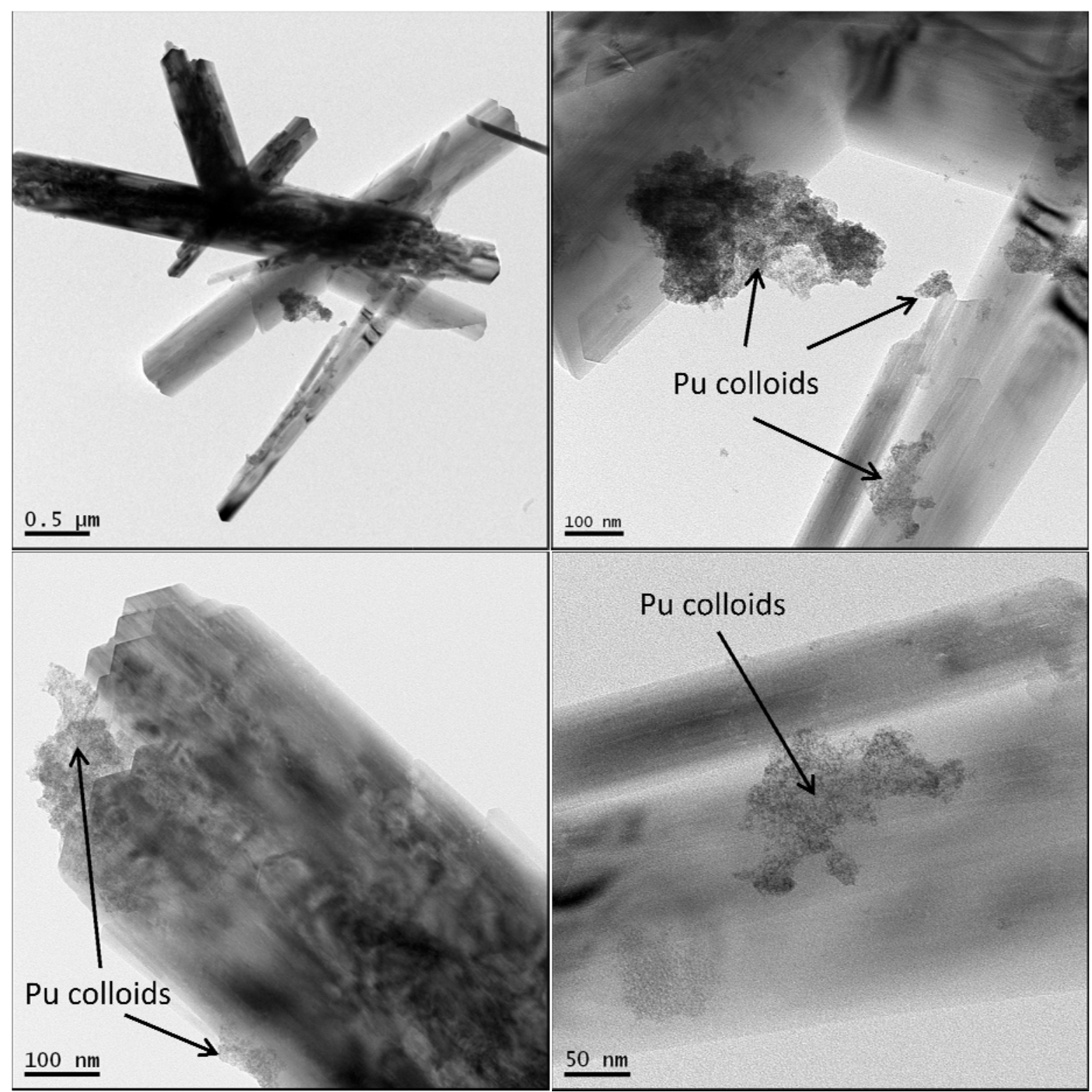

Figure 8. TEM of intrinsic Pu(IV) nano-colloids sorbed to goethite at $25^{\circ} \mathrm{C}$ for 103 days in the high concentration sample. The 9,400 ppm Pu on goethite represents $\sim 50 \%$ surface load. Arrows identify locations where aggregated (Agg) $\mathrm{PuO}_{2}$ nano-colloids are present. 

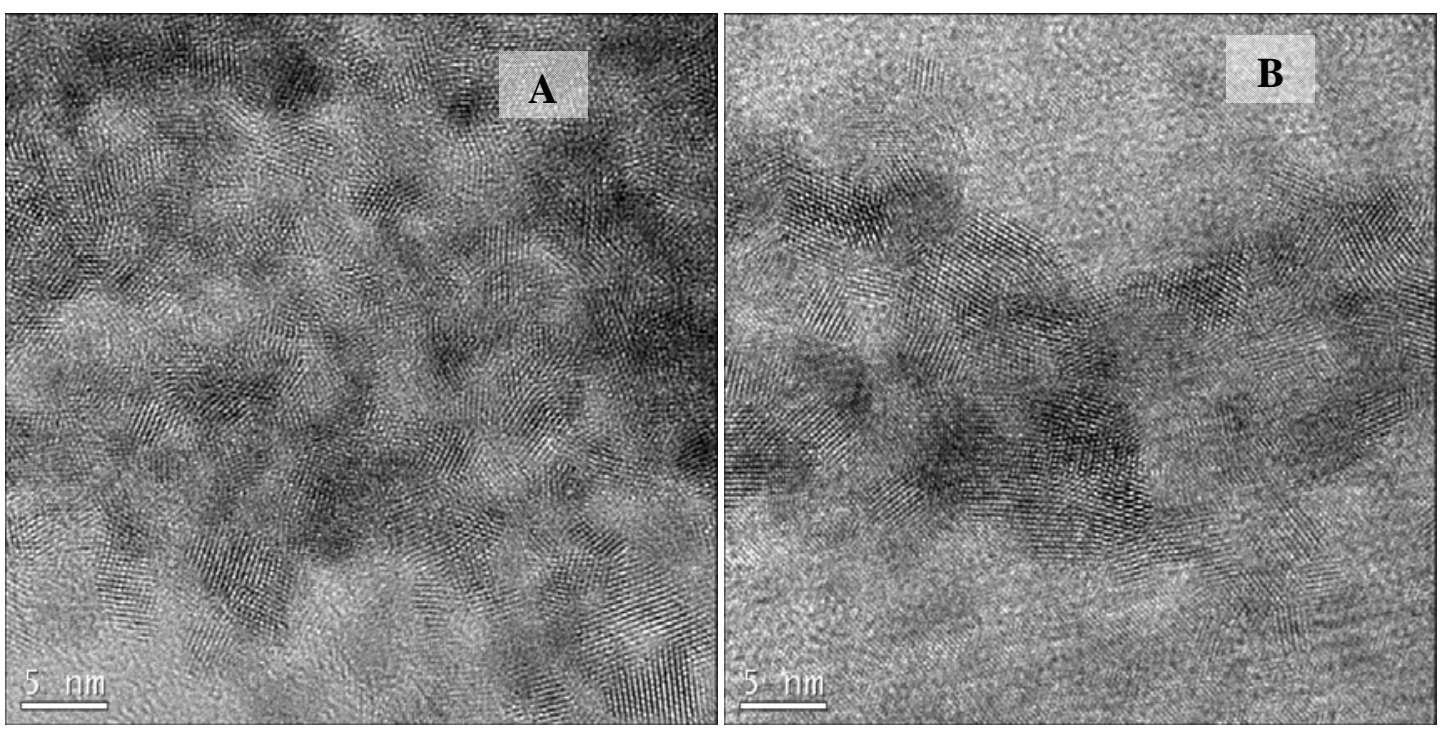

Figure 9. HRTEM of intrinsic $\mathrm{Pu}(\mathrm{IV})$ nano-colloids sorbed to goethite at $25^{\circ} \mathrm{C}$ for 103 days. 9,400 $\mathrm{ppm} \mathrm{Pu}$ on goethite ( 50\% surface load). Aggregated fcc $\mathrm{PuO}_{2}$ colloids on carbon support film (A) and aggregated fcc $\mathrm{PuO}_{2}$ colloids on goethite (B).

\section{$\underline{80^{\circ} \mathrm{C} \text { aqueous } \mathrm{Pu}}$}

The characteristics of Pu associated with goethite at $80^{\circ} \mathrm{C}$ are not substantially different from those at $25^{\circ} \mathrm{C}$. The intermediate concentration aqueous $\mathrm{Pu}(\mathrm{IV})$ sample is dominated by dispersed $\mathrm{Pu}_{4} \mathrm{O}_{7}$ nano-colloids that are in the 2-5 nm size range (Figure 10; compare to Figure 5). In the high concentration sample, both aggregated $\mathrm{PuO}_{2}$ nano-colloids and dispersed $\mathrm{Pu}_{4} \mathrm{O}_{7}$ nanocolloids are present (Figures 11 and 12; compare to Figure 6). The aggregated $\mathrm{PuO}_{2}$ nanocolloids are located both on and off the goethite surface while the $\mathrm{Pu}_{4} \mathrm{O}_{7}$ nano-colloids are strictly associated with the goethite surface. At $80^{\circ} \mathrm{C}$, the size of the aggregated $\mathrm{PuO}_{2}$ nanocolloids appears to be larger. This is consistent with Pu concentrations measured in solution (Figure 4) which suggest a significant fraction of intrinsic Pu(IV) nano-colloids are aggregated and in the $25-250 \mathrm{~nm}$ particle size range.

\section{$\underline{80^{\circ} \mathrm{C} \text { intrinsic Pu nano-colloids }}$}

The behavior of intrinsic $\mathrm{Pu}(\mathrm{IV})$ nano-colloids at $80^{\circ} \mathrm{C}$ is dominated in both intermediate and high concentration samples by the formation of aggregated $\mathrm{PuO}_{2}$ nano-colloids and little if any association with the goethite surface (Figures 13 to 15). The high concentration sample is dominated by large mats of aggregated $\mathrm{PuO}_{2}$ nano-colloids with sizes in the 2-5 nm range. In terms of bulk solution chemistry, these would be considered precipitates of $\mathrm{PuO}_{2}$ (am, hyd). HRTEM images and electron diffraction analysis indicates that the mats are composed of 2-5 nm nano-colloids with a fcc $\mathrm{PuO}_{2}$ structure. Importantly, the results suggest that the relationship between colloidal and precipitated forms of $\mathrm{PuO}_{2}$ (am, hyd) is controlled by degree of aggregation of 2-5 nm nano-colloids. Aggregation of nano-colloids is controlled primarily by the solution conditions in which they are present (Pu concentration, solution composition (e.g. ionic strength, $\mathrm{pH}$ ) and temperature). Thus, the concentration of dispersed intrinsic $\mathrm{PuO}_{2}$ nano- 
colloids in solution will most likely be controlled by the physical aggregation behavior of $\mathrm{PuO}_{2}$ nano-colloids.

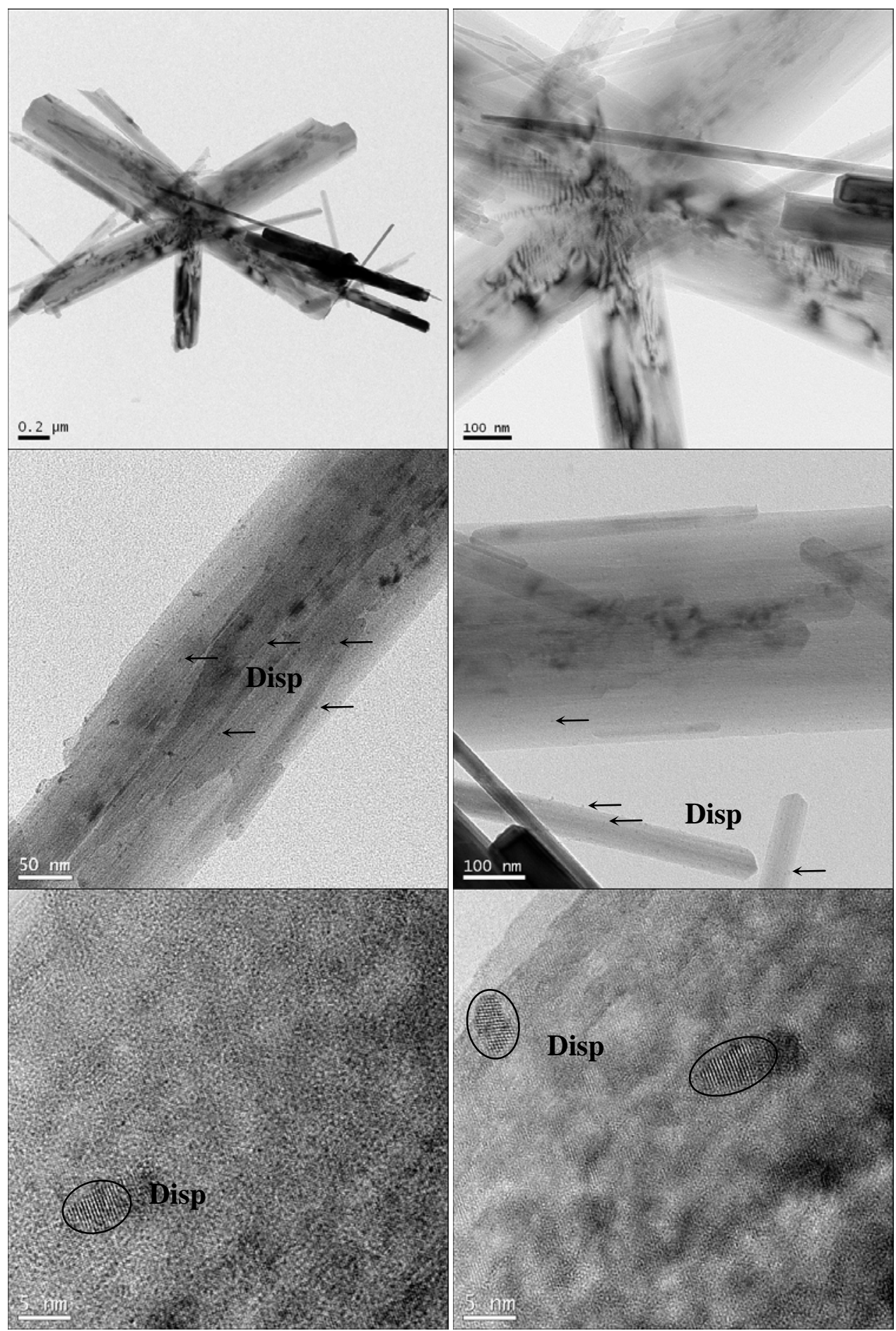

Figure 10. TEM/HRTEM of aqueous $\mathrm{Pu}(\mathrm{IV})$ sorbed to goethite at $80^{\circ} \mathrm{C}$ for 103 days. $1,700 \mathrm{ppm}$ Pu on goethite ( 10\% surface load). Arrows and circles identify locations where dispersed (Disp) $\mathrm{Pu}_{4} \mathrm{O}_{7}$ nano-colloids are present. 


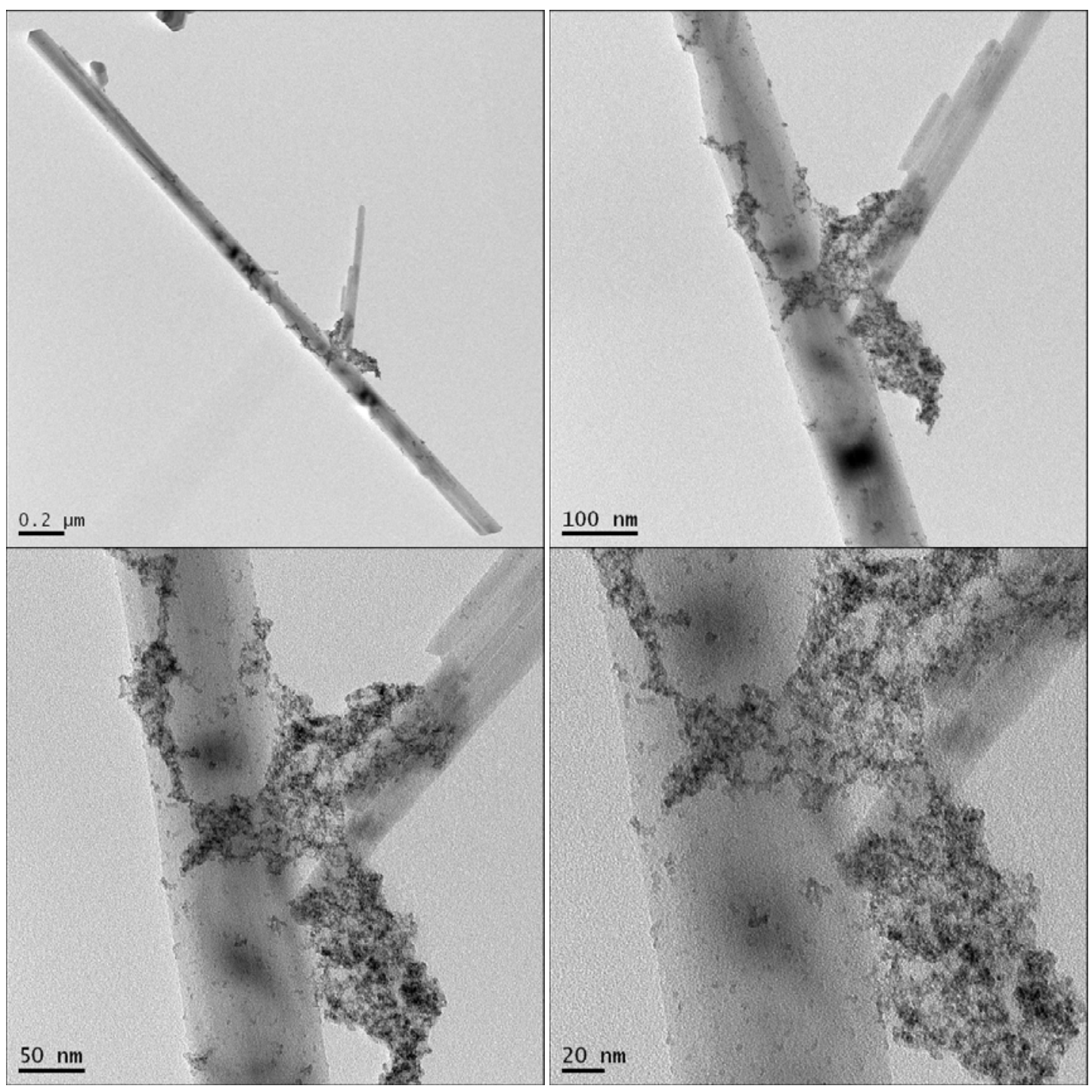

Figure 11. TEM of aqueous $\mathrm{Pu}(\mathrm{IV})$ sorbed to goethite at $80^{\circ} \mathrm{C}$ for 103 days for the high concentration sample. The $8,900 \mathrm{ppm}$ Pu on goethite represents $\sim 50 \%$ surface load. Arrows and circles identify locations where aggregated (Agg.) $\mathrm{PuO}_{2}$ and dispersed (Disp) $\mathrm{Pu}_{4} \mathrm{O}_{7}$ nano-colloids are present. 

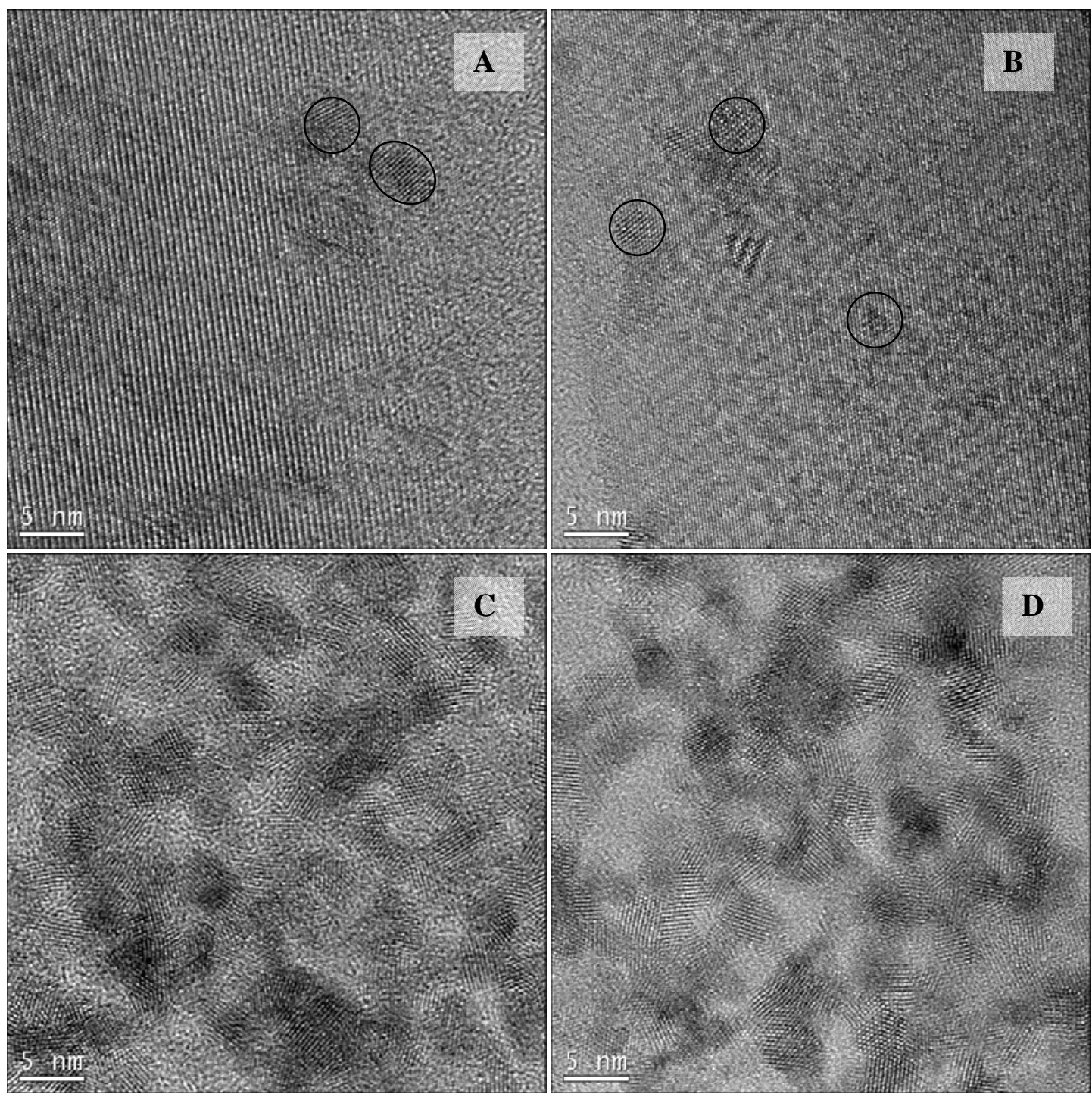

Figure 12. HRTEM of aqueous $\mathrm{Pu}(\mathrm{IV})$ sorbed to goethite at $80^{\circ} \mathrm{C}$ for 103 days for the high concentration sample. The 8,900 ppm Pu on goethite represents $~ 50 \%$ surface load. Both dispersed (Disp) $\mathrm{Pu}_{4} \mathrm{O}_{7}$ nano-colloids (A, B) and aggregated (Agg) $\mathrm{PuO}_{2}$ nano-colloids (C, D) are present. 

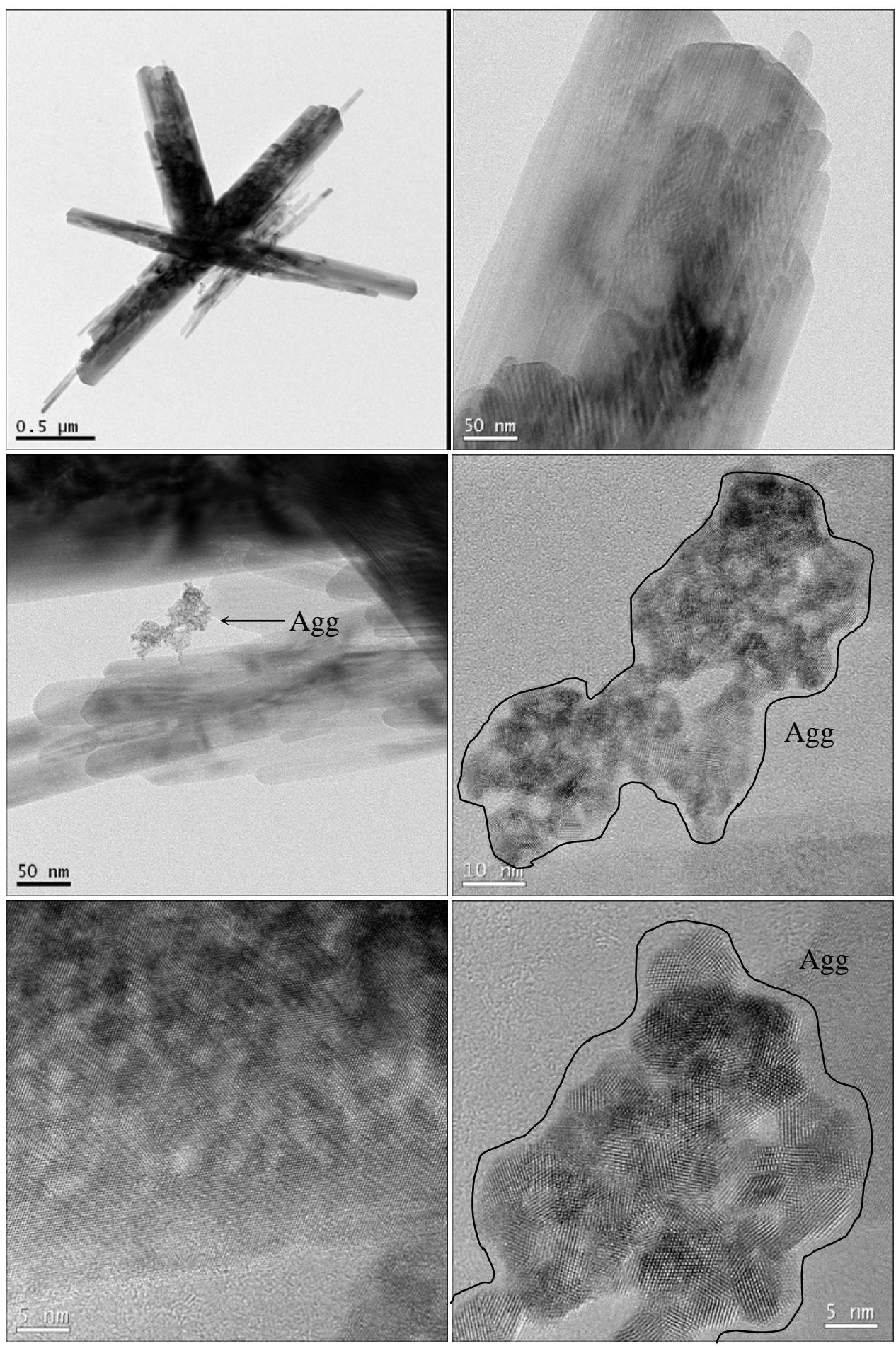

Figure 13. TEM/HRTEM of intrinsic Pu(IV) nano-colloids sorbed to goethite at $80^{\circ} \mathrm{C}$ for 103 days of the intermediate sample. The 2,100 ppm Pu on goethite represents $~ 10 \%$ surface load. Arrows and circles identify locations where aggregated (Agg) nano-colloids are present. Goethite surfaces had no identifiable Pu nano-colloids present. Some aggregated Pu nano-colloids were observed weakly associated with goethite. HRTEM images show aggregated fcc $\mathrm{PuO}_{2}$ colloids. 


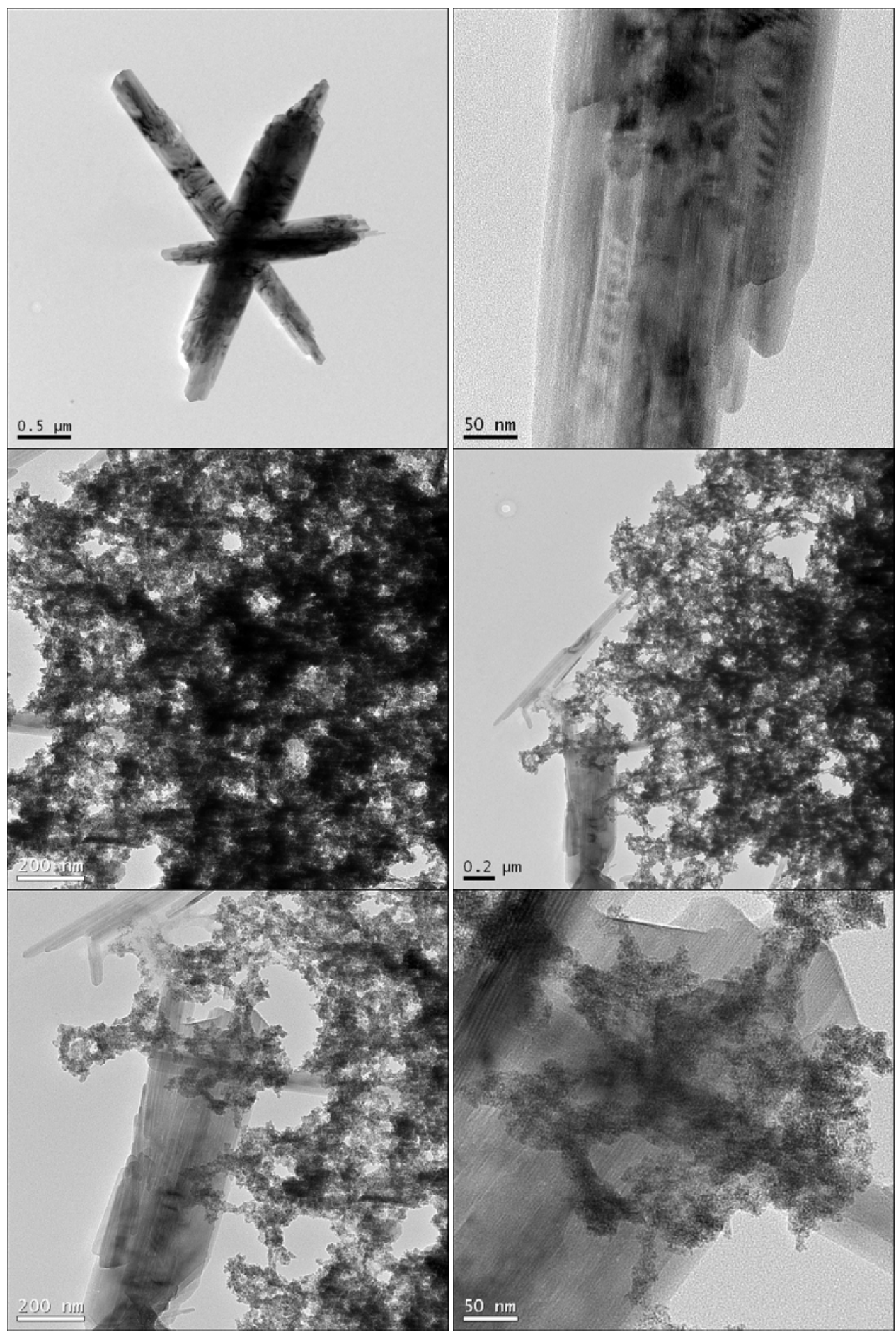

Figure 14. TEM of intrinsic Pu(IV) nano-colloids sorbed to goethite at $80^{\circ} \mathrm{C}$ for 103 days of the high concentration sample. The 10,000 ppm Pu on goethite represents 50\% surface load. Goethite surfaces have no identifiable Pu nano-colloids present. Aggregated $\mathrm{Pu}(\mathrm{IV})$ nano-colloids are weakly associated with goethite. 

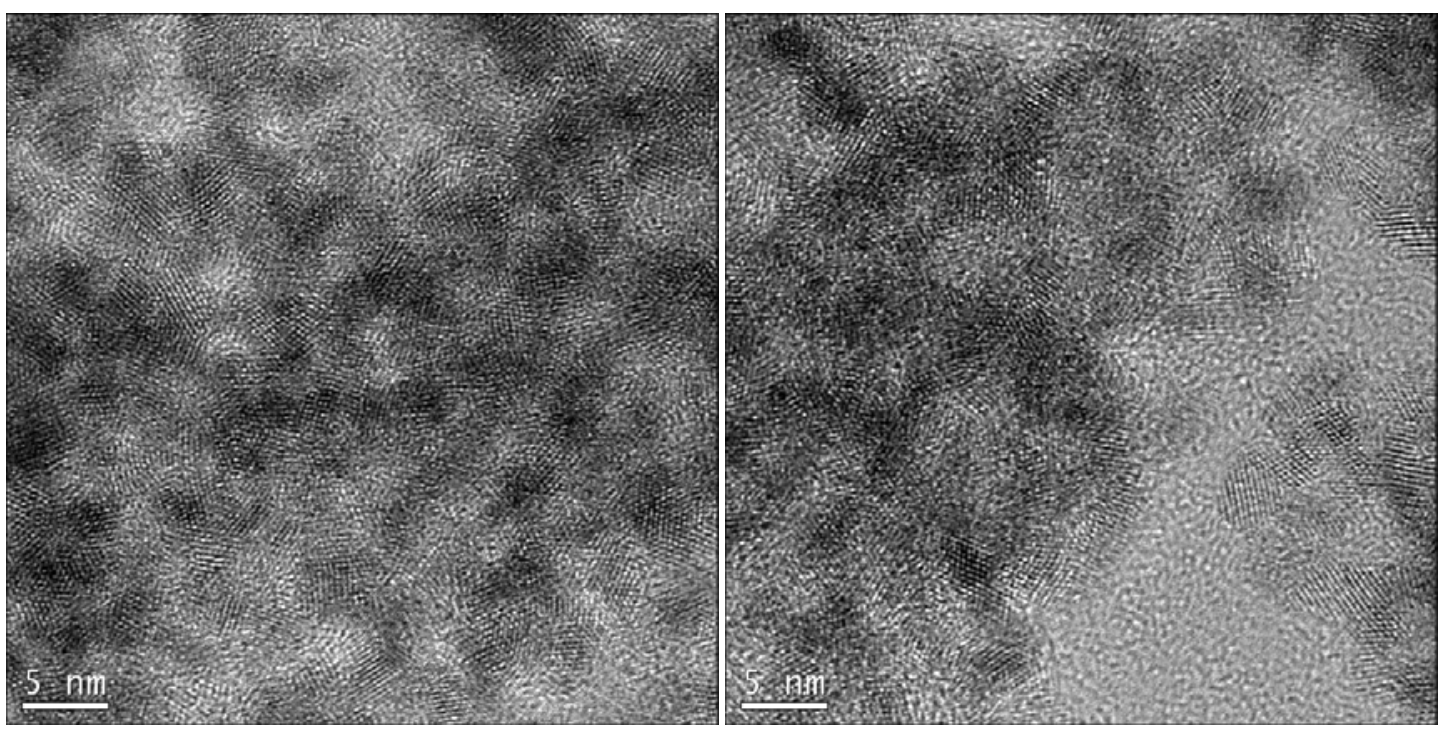

Figure 15. HRTEM of intrinsic Pu(IV) nano-colloids sorbed to goethite at $80^{\circ} \mathrm{C}$ for 103 days of a high concentration sample. The 10,000 ppm Pu on goethite represents $~ 50 \%$ surface load. The aggregated 2-5 nm Pu nano-colloids have a fcc $\mathrm{PuO}_{2}$ crystal structure.

\section{SUMMARY}

We have examined the behavior of aqueous $\mathrm{Pu}(\mathrm{IV})$ and intrinsic $\mathrm{Pu}(\mathrm{IV})$ nano-colloids and interaction with goethite at 25 and $80^{\circ} \mathrm{C}$ and over a range of concentrations from undersaturated to oversaturated with respect to $\mathrm{PuO}_{2}$ (am, hyd). In the presence or absence of goethite, temperature does not appear to greatly affect Pu concentrations in solution. The strong affinity of aqueous $\mathrm{Pu}(\mathrm{IV})$ for the goethite surface is explained by the epitaxial growth of bcc $\mathrm{Pu}_{4} \mathrm{O}_{7}$ nano-colloids on the goethite substrate. The behavior is affected minimally by temperature. This strong affinity cannot be achieved when intrinsic $\mathrm{Pu}(\mathrm{IV})$ nano-colloids are reacted with goethite over 103 days. The results indicate that the fate of $\mathrm{Pu}$ is dependent on its initial form and its subsequent stability under changing geochemical conditions. Epitaxial growth of $\mathrm{Pu}_{4} \mathrm{O}_{7}$ on the goethite surface will produce a strong association between $\mathrm{Pu}$ and goethite, which could also lead to significant colloid-facilitated transport. Both intrinsic colloids and those sorbed to goethite have the potential to be transported with groundwater. The long-term stability and desorption characteristics of these forms of colloidal $\mathrm{Pu}$ will be the focus of ongoing research in FY12. A comprehensive characterization of Pu sorbed to other minerals, such as, clays is the subject of ongoing research in FY11 and FY12.

\section{ACKNOWLEDGEMENTS}

This work was performed with funding from the Department of Energy, Nuclear Energy Used Fuel Disposition Program. This work performed under the auspices of the U.S. Department of Energy by Lawrence Livermore National Laboratory under Contract DE-AC52-07NA27344. 


\section{REFERENCES}

Demirkanli, D.I., Molz, F.J., Kaplan, D.I., Fjeld, R.A., 2008. A fully transient model for longterm plutonium transport in the Savannah River Site vadose zone: Root water uptake. Vadose Zone Journal 7, 1099-1109.

Dzombak, D.A., Morel, F.M.M., 1990. Surface complexation modeling : hydrous ferric oxide. Wiley, New York.

Garcia-Garcia, S., Wold, S., Jonsson, M., 2009. Effects of temperature on the stability of colloidal montmorillonite particles at different $\mathrm{pH}$ and ionic strength. Applied Clay Science 43, 21-26.

Gee, G.W., Bauder, J.W., 1986. Particle-size Analysis, in: Klute, A. (Ed.), Methods of Soil Analysis: Part I - Physical and Mineralogical Methods. American Society of Agronomy, Inc, Madison, WI, pp. 383-411.

Glynn, P.D., 2003. Modeling Np and Pu transport with a surface complexation model and spatially variant sorption capacities: implications for reactive transport modeling and performance assessments of nuclear waste disposal sites. Computers \& Geosciences 29, 331-349.

Kaplan, D.I., Powell, B.A., Demirkanli, D.I., Fjeld, R.A., Molz, F.J., Serkiz, S.M., Coates, J.T., 2004. Influence of oxidation states on plutonium mobility during long-term transport through an unsaturated subsurface environment. Environmental Science \& Technology 38, 5053-5058.

Kaplan, D.I., Powell, B.A., Gumapas, L., Coates, J.T., Fjeld, R.A., Diprete, D.P., 2006. Influence of $\mathrm{pH}$ on plutonium desorption/solubilization from sediment. Environmental Science \& Technology 40, 5937-5942.

Kersting, A.B., Efurd, D.W., Finnegan, D.L., Rokop, D.J., Smith, D.K., Thompson, J.L., 1999. Migration of plutonium in ground water at the Nevada Test Site. Nature 397, 56-59.

Neck, V., Altmaier, M., Seibert, A., Yun, J.I., Marquardt, C.M., Fanghanel, T., 2007. Solubility and redox reactions of $\mathrm{Pu}(\mathrm{IV})$ hydrous oxide: Evidence for the formation of $\mathrm{PuO} 2+\mathrm{x}(\mathrm{s}$, hyd). Radiochimica Acta 95, 193-207.

Novikov, A.P., Kalmykov, S.N., Utsunomiya, S., Ewing, R.C., Horreard, F., Merkulov, A., Clark, S.B., Tkachev, V.V., Myasoedov, B.F., 2006. Colloid transport of plutonium in the farfield of the Mayak Production Association, Russia. Science 314, 638-641.

Pickett, D.A., 2005. Approach to assessing the potential effects of colloidal radionuclide transport on nuclear waste repository performance. Nuclear Science and Engineering 151, 114-120.

Powell, B.A., Dai, Z., Zavarin, M., Zhao, P., Kersting, A.B., in press. Stabilization of plutonium nano-colloids by epitaxial distortion on mineral surfaces. Environmental Science \& Technology. 
Powell, B.A., Fjeld, R.A., Kaplan, D.I., Coates, J.T., Serkiz, S.M., 2005. Pu(V)O2+ adsorption and reduction by synthetic hematite and goethite. Environmental Science \& Technology 39, 2107-2114.

Powell, B.A., Kersting, A.B., Zavarin, M., 2008a. Sorption and Desorption Rates of Neptunium and Plutonium on Goethite, in: Zavarin, M., Kersting, A.B., Lindvall, R.E., Rose, T.P. (Eds.), Hydrologic Resources Management Program and Underground Test Area Project, FY 2006 Progress Report. Lawrence Livermore National Laboratory, Livermore, CA, pp. 90, UCRL-TR-404620.

Powell, B.A., Kersting, A.B., Zavarin, M., 2008b. Sorption and desorption rates of neptunium and plutonium on goethite, in: Zavarin, M., Kersting, A.B., Lindvall, R.E., Rose, T.P. (Eds.), Hydrologic resources management program and underground test area project, FY 2006 progress report. U.S. Department of Energy, Lawrence Livermore National Laboratory.

Schwertmann, U., Cornell, R., M., 1991. Iron oxides in the laboratory: preparation and characterization. VCH Verlagsgesellschaft mbH, Weinheim.

Tien, N.C., Jen, C.P., 2007. Analytical modeling for colloid-facilitated transport of N-member radionuclides chains in the fractured rock. Nuclear Science and Techniques 18, 336-343.

U.S. Department of Energy, O.o.B.E.S., 2007. Basic research needs for geosciences: facilitating 21st century energy systems. Report from the Workshop Held February 21-23, 2007, Bethesda, MD.

Xu, C., Santschi, P.H., Zhong, J.Y., Hatcher, P.G., Francis, A.J., Dodge, C.J., A., R.K., Hung, C.C., Honeyman, B.D., 2006. Colloidal Cutin-Like SubstancesCross-Linked to Siderophore Decomposition Products Mobilizing Plutonium from Contaminated Soils. Env. Sci. \& Tech 42, 211-216

Zhao, P., Zavarin, M., Tumey, S., Williams, R., Dai, Z., Kips, R., Kersting, A.B., 2010. Isotherm of Pu/Goethite System: Linearity and Sorbent Surface Characterization, AGU Fall Meeting, San Francisco. 